\title{
Kautilya on Foresight, Oversight, Regulations, Ethics and Systemic Risk
}

\author{
Balbir S. Sihag \\ University of Massachusetts Lowell, Lowell, USA \\ Email: balbir_sihag@uml.edu
}

How to cite this paper: Sihag, B.S. (2017) Kautilya on Foresight, Oversight, Regulations, Ethics and Systemic Risk. Theoretical Economics Letters, 7, 352-364. https://doi.org/10.4236/tel.2017.73027

Received: February 15, 2017

Accepted: March 19, 2017

Published: March 22, 2017

Copyright $\odot 2017$ by author and Scientific Research Publishing Inc. This work is licensed under the Creative Commons Attribution International License (CC BY 4.0).

http://creativecommons.org/licenses/by/4.0/

\begin{abstract}
In the wake of the recent Great recession of 2008-9, prudential supervision and "too-big-to-fail" have become the focal topics of discussion and policy. Western countries have added prudential supervision to complement the traditional regulatory approach to prevent reoccurrence of financial crisis. Additionally, large financial institutions are subjected to repeated "stress tests" to diagnose the vulnerability of the financial system. Kautilya had argued a long time ago that moral failure was the primary source of the systemic risk. Keeping that in view, relevance of his three insights is presented. Firstly, regulations, prudential supervision and ethical grounding are needed for preventing future financial crisis. That is, current approach of relying only on regulations and supervision, most probably would not prevent future financial crisis. Secondly, if moral hazard resulting from moral failure is the primary source of systemic risk, undue focus on "too-big-to-fail" financial institutions is unwarranted. Thirdly, Financial Stability Oversight Council's two objectives, promoting market discipline and prevention of another financial crisis, do not seem to be compatible with each other.
\end{abstract}

\section{Keywords}

Ethical Grounding, Foresight, Oversight, Moral Hazard, Moral Failure,

"Too-Big-to-Fail”, Systemic Risk

\section{Introduction}

The severity of financial crisis of 2008 and its spread throughout the world at an alarming speed shocked everyone. The precipitous fall in equity and real estate prices, the home foreclosures, the fear of a looming deeper and longer recession and the worsening of job markets caused almost an unbearable level of anxiety among workers, manufacturers, homeowners and investors all over the world. A considerable amount of intellectual effort has been devoted to defining, measur- 
ing and preventing systemic risk. Various measures by governments all over the world also have been undertaken to prevent the reoccurrence of such near disaster. For example, in the US, Dodd-Frank Act established the Financial Stability Oversight Council (FSOC) to identify risks and suggest measures to prevent another financial crisis. Further, as mentioned in Sanchis [1] the UE set up a new regulatory framework to safeguard European financial stability is organised around two pillars the European Council of Systemic Risk (ECSR) which aims at macro prudential supervision; and, the European System of Financial Supervisors (ESFS) that is entrusted with micro prudential harmonisation, that is, to establish a network of national financial supervisors who will work closely with the new European Financial Supervisory Authorities

Kautilya was the first economist, who had argued that maintenance of both peace and prosperity, to a large extent, depended on preparedness and that required foresightedness. This insight needs to be driven home since the new US administration is proposing to weaken the Dodd-Frank bill that had incorporated foresightedness for identifying threats to financial stability. Also, oversight without foresight would be sightless and consequently might be close to being useless. According to Kautilya, the decision-makers must be foresighted. Section 2 contains this discussion. For over two hundred years an economic system has been compared to a machine. Such comparison is inappropriate since parts of a machine do not negotiate with each other the terms and conditions of engagement and similarly, no part of a machine ever displays moral hazard or strategic behavior but people, who are the primary constituents of an economic system, do. Anyhow, such comparison was harmless, though inappropriate, to treat the baker, the barber and the butcher as parts of a machine but now it could be disastrous since it diverts attention away from the source of systemic risk. On the other hand, Kautilya believed that a kingdom or a system consisted of people (policy-makers and others) and things. Such characterization of a system allows a more meaningful analysis of systemic risk. Kautilya's ideas on economic system and systemic risk are discussed in Section 3.

Establishment of the FSOC is the step in the right direction since by adding oversight to complement the regulatory approach would reduce the probability of another financial crisis. Historically speaking, legislations creating FDIC and the unemployment compensation, to some extent, have stopped runs on otherwise healthy banks and helped the unemployed pay their bills. But these legislations have created the moral hazard problem. The depositors of small amounts do not feel the need to pay attention to the risky behavior of bankers and the unemployed do not feel the pressure to actively search for jobs ${ }^{1}$. Tax-payers bailed-out the troubled Savings \& Loan Associations during the 1980s and 1990s and the big financial institutions during the recent Great recession. That has created a built-in expectation that the tax-payers would bail-out if there were to be another financial crisis. Consequently, the shareholders and creditors, most 
probably have become lax and not keen on guarding against the risky behavior of bankers and others. That is, it has become, in addition to FDIC and unemployment compensation, another case of moral hazard problem.

FSOC has been assigned the task of promoting market-discipline to eliminate such expectations, that is, to drive home the point that tax-payers would not come to their rescue. However, market discipline, most likely would be powerless in preventing another financial crisis ${ }^{2}$. Perhaps that was the most important lesson learnt from the great depression of the 1930s. Therefore, the issue at stake is the following: are FSOC's two objectives, promoting market discipline and prevention of another financial crisis, compatible with each other? Relevance of Kautilya's insights to answering this question is presented in Section 4.

Kautilya was not religious but was ethical and secular. He strongly believed in the link between good character and good behavior. The Spanish philosopher Ortega y Gasset emphasizes the importance of the circumstance in one's behaviour [2]. [3] Samuel Buell (2016) claims that situation and context are more relevant than a person's character in explaining his/her behavior. Similarly, [4] Eugene Soltes (2016) casts doubt on the link between good character and good behavior. He unknowingly, perhaps uses Adam Smith's concept of self-command to conclude that character was not important in explaining one's behavior. It is indicated that the concept of self-command is useless in dealing with greed or moral hazard, the underlying factor for committing majority of the white collar crimes. On the other hand, Kautilya's concept of self-discipline is most appropriate in controlling vices, such as greed, lust and moral hazard. Keeping that in view, he recommended ethical mooring of the children. This discussion is presented in Section 5. Final section contains some concluding observations.

\section{Kautilya on the Role of Foresight}

Kautilya was the first economist, who emphasized the critical role of foresightedness in preventing economic crisis. Kautilya's predecessors considered possession of foresight as a life saver. They wrote animal fables to teach the young to develop this component of wisdom. [5] Kautilya (p. 205) also warned a would-be adviser to the king as: "A wise man makes self-protection his first and constant concern (5.416.17)." However, he extended its role in many directions. If a ruler (CEO) did not foresee a threat, he would not be prepared to take any preventive or remedial measures. According to Kautilya, foresightedness was required in undertaking both preventive and remedial measures to handle a potential threat arising from an attack, occurrence of a famine or moral decay. He (p. 116) wrote, "In the interests of the prosperity of the country, a king should be diligent in fo-

${ }^{2}$ [14] Christoffer Koch, Gary Richardson and Patrick Van Horn (2016) conclude, "The changing behavior of money-center banks is consistent with the theoretical literature on the impact of too-bigto-fail policies and modern prudential policy initiatives, such as procyclical capital requirements and enhanced reliance on market discipline designed to offset moral hazard. Our findings further suggest that scholars and policy makers alike need to be realistic about the potential benefits of institutional and regulatory reforms. While the institutional framework of the 1920s induced money-center banks to hold excessive capital relative to risk, the United States and international financial systems still collapsed, aggravating the longest, deepest global downturn in modern history." 
reseeing the possibility of calamities, try to avert them before they arise, overcome those which happen, remove all obstructions to economic activity and prevent loss of revenue to the state (8.4)."

Qualification of an Adviser. Kautilya (p. 120) described, "A councilor or minister of the highest rank should be a native of the state, born in a high family and controllable [by the king]. He should have been trained in all the arts and have logical ability to foresee things. He should be intelligent, persevering, dexterous, eloquent, energetic, bold, brave, and able to endure adversities and firm in loyalty. He should neither be haughty or fickle. He should be amicable and not excite hatred or enmity in others (1.9).”

Recently, Financial Stability Oversight Council was established by the DoddFrank Wall Street Reform, unfortunately, now might be reversed by the new US administration, and Consumer Protection Act (Dodd-Frank Act) and is charged with three primary purposes:

1) To identify risks to the financial stability of the United States that could arise from the material financial distress or failure, or ongoing activities, of large, interconnected bank holding companies or nonbank financial companies, or that could arise outside the financial services marketplace.

2) To respond to emerging threats to the stability of the US financial system.

3) To promote market discipline, by eliminating expectations on the part of shareholders, creditors, and counterparties of such companies that the US government will shield them from losses in the event of failure.

A few remarks are in order. Perhaps for the first time in US history, authorities appreciated the importance of foresight in identifying the threats to financial stability. Secondly, policy-makers realized the inadequacy of regulations and therefore, added oversight to complement regulations in reducing the probability of another financial crisis (see more in Section 3). That implies that Buell's concerns have been addressed ${ }^{3}$. Kautilya had emphasized that an adviser must have the "logical ability to foresee". However, members of the FSOC are not required to be foresighted.

\section{Kautilya on an Economic System and Systemic Risk}

Adam Smith compared an economic system to a machine and despite its inappropriateness, this metaphor has not lost its appeal ${ }^{4}$. For example, according to [6] Jean-Pierre Zigrand (2014), "A social system on the other hand must be functioning, or as Vining (1984) says, it must be a working thing, a machine functioning towards accomplishing an aim, an aim embedded in the principle of

\footnotetext{
${ }^{3}$ Samuel Buell (2016, pp 81-82) remarks, "Even without the messiness of democracy, law would be a flawed technology. Laws can never quite reach their intended targets, for two reasons. First, human ingenuity and foresight are always limited, especially when predicting the paths that our species will take. Laws must anticipate futures that the people who make laws cannot clearly see. Legal rules will inevitably end up confronting innovations for which they were not designed."

${ }^{4}$ Adam Smith (1795, p 60) wrote, "Systems in many respects resemble machines. A machine is a little system, created to perform, as well as to connect together, in reality, those different movements and effects which the artist has occasion for. A system is an imaginary machine invented to connect together in the fancy those different movements and effects which are already in reality performed."
} 
deductibility from the axiom of economicity. It may not be perfect, but it possesses some minimal requirements, not least consistency, coherence and an ongoing goal."

A few remarks are in order. First, an economic system consists of decision makers and things. Zigrand and others focus only on the things and leave out the people, who make policies, oversee, regulate and manage the things. That is, a mechanistic definition of an economic system leaves out its core, the people. On the other hand, Kautilya focused primarily on people. He (p. 116) wrote, "It is the people who constitute a kingdom (7.11.24)." He listed seven elements or constituents of a state. According to him, these were i) the king, ii) councilors, ministers and other high officials, iii) public and the territory, iv) the fortified towns and cities, v) treasury, vi) army, and vii) allies, that is, a kingdom or an economic system consists of people and things ${ }^{5}$.

Secondly, a machine does not have any emergent properties. It has merely predictive and repetitive movements. Thirdly, a high degree of linkages among financial firms needs to be seen as a sign of high degree of specialization and of a vibrant economy and not merely as a propagating mechanism of systemic risk. Further, "the deliberate ignorance of the systemic risk factors or the incapacity to signal the public that these factors are conducive to a certain 'academic moral hazard"', also matters [7] Sanchis (2014), and Colander et al. (2009).

A machine does not care who gets the produce and does not understand the pain and hardship of Sinclair's (1906) Jurgis Rudkus. In fact, Kautilya (p. 122) defines a calamity as: "That which deprives a person of his strength and goodness is a vyasana (a vice, adversity or calamity (8.1.4)." People are deprived of "strength and goodness" implying that a mechanistic definition of a system could not capture the impact of a crisis on an individual's emotional and physical health. Incidentally, Kautilya included addiction, such as to opioids or narcotics as a calamity since that too "deprives a person of his strength and goodness".

Systemic Risk: According to [8] Zachary Feinsteina, Birgit Rudloffb and Stefan Weber (2016), "Systemic risk refers to the risk that the financial system is susceptible to failures due to the characteristics of the system itself. The tremendous cost of this type of risk requires the design and implementation of tools for the efficient macro-prudential regulation of financial institutions. The current paper proposes a novel and general approach to systemic risk measurement."

Almost all the academicians and policy makers consider the characteristics, such as leverage, size, mismatch between the maturities of assets and liabilities, and asset prices etc., of the system as the source of the systemic risk. Accordingly, managing the characteristics through regulation and supervision is recommended to prevent another financial crisis and stress tests are carried out to diagnose its vulnerability. But that is a misdiagnosis of the source of systemic risk and unwarranted reliance on stress tests. Suppose a person has low hemoglobin, boosting it through an iron-rich diet or blood infusion may seem appropriate.

${ }^{5}$ Samuel Buell (2016, p xii) remarks, "GM is a corporation. It does not think, it can't drive a car, and it can't even really be seen. It's an amalgam of people, factories, vehicles, images, and spread across the globe. GM is an idea as much as it is a thing." 
However, if hemoglobin is low due to blood cancer, these remedies would be only of temporary help and would not reduce the probability of a health disaster. Similarly, if moral hazard problem is system-wide like the blood cancer, raising the capital requirement might seem appropriate but would not reduce the probability of a financial disaster. That means, moral hazard, not the characteristics, is the real source of the systemic risk. In other words, characteristics of the system depend on the character of the policy makers, bankers and hedge fund managers etc., implying that decision-makers' behavior is the real source of systemic risk. It is generally acknowledged that moral hazard problem is wide spread and the S \& L loans crisis and the 2008 financial crisis may be attributed to it, implying so far as the source of systemic risk is concerned "too big to fail" is not that a big problem but ethical failing could be a very big problem ${ }^{6}$.

Kautilya on the Link between Moral Decay and Systemic Risk: Kautilya was the first economist, who understood the link between ethical conduct and prosperity. He believed that the survival as well as prosperity of a kingdom depended on the ethical conduct of both the ruler and public. He (pp. 107-08) surmised, "For the world, when maintained in accordance with the Vedas, will ever prosper and not perish. Therefore, the king shall never allow the people to swerve from their dharma." $\mathrm{He}$ (p. 141) wrote, "A king who flouts the teachings of the Dharamshastras and The Arthashastra, ruins the kingdom by his own injustice (8.2)." He believed that ethical decision-makers would not fail in their duties and would not promote their private interests at the expense of public interest. Similarly, he believed that "greed clouds the mind", implying that a greedy person could not figure out the consequences of his/her actions. According to him, moral hazard problem and greed would be non-existent in an ethical society. In fact, Kautilya's predecessors had emphasized the foundational role of dharma (ethics). For example, according to [9] Atharva Veda (12-1-17), "This World is Upheld by Dharma." Kautilya wholeheartedly accepted and promoted the secular virtues (dharmic duties). He $(1992,107)$ wrote, "Duties common to all: Ahimsa [abstaining from injury to all living creatures]; satyam [truthfulness]; cleanliness; freedom from malice; compassion and tolerance (1.13)."

However, "too big to fail" plays an important role in the propagation of systemic risk. Input-output matrices were constructed to trace the impact of a change in one industry on other industries. Until the oil shock of 1973, energy

${ }^{6}$ Kautilya understood the concept of propagation. He (p. 634) wrote, "A small revolt in the rear outweighs a large gain in the front; for, when the king is not there, a small revolt in the rear may be worsened by the anger of the people or by traitors, enemies and jungle tribes. If this happens, a large gain in front, even if actually obtained, will be eaten up by the subjects, allies, losses and expenses. Therefore, a king shall not undertake a campaign when the gain in front is [less than] a thousand times the likely loss due to a revolt in the rear or, at least, a hundred times the loss. A well-known proverb is: 'Misfortunes are, [in the beginning] no longer than the point of a needle' (9.3)."

[15] Markus K. Brunnermeier and Martin Oehmke (2012): "For the more recent housing bubble, the triggering event seems clearer. Blame is usually laid on the subprime mortgage market that began to turn sour in late 2006 . However, the subprime market constituted only about $4 \%$ of the overall mortgage market. This leads to the question, how can such "small" news cause so much damage? And how can a crisis that originates in the subprime mortgage market propagate across so many sectors of the economy?" 
Matrix 1. Inter-linkages among Financials.

\begin{tabular}{cccc}
\hline & Banks & Brokerage Firms & Hedge Funds \\
\hline Banks & $\mathrm{B}_{11}$ & $\mathrm{~B}_{12}$ & $\mathrm{~B}_{13}$ \\
Brokerage Firms & $\mathrm{B}_{21}$ & $\mathrm{~B}_{22}$ & $\mathrm{~B}_{23}$ \\
Hedge Funds & $\mathrm{B}_{31}$ & $\mathrm{~B}_{32}$ & $\mathrm{~B}_{33}$ \\
\hline
\end{tabular}

cost was so insignificant that no one felt the need to keep records. As a result, no one knew at the time what would be the impact of the oil shock. Although inter-financials linkages are not the source of systemic risk but it would be helpful in understanding the strength of linkages. Dodd-Frank Act has established the Office of Financial Research (OFR) to collect data on inter-linkages among financial firms. Something similar Matrix 1.

It will be useful to construct appropriate input-output tables that incorporate the financial sector. It can reveal all the linkages among the financial firms for understanding the domino effect and between the financial sector and the other sectors for possible gauzing of the liquidity effect ${ }^{7}$.

\section{Relevance of Kautilya's Insights to Preventing Financial Crisis}

Indifference curves are convex to the origin if both the commodities are goods, that is, more the better. If one is good like a return on an asset and the other is bad like the risk on the asset, the indifference curves are positively sloped. Businesses consider both oversight and regulations as bads, that is, lower the better, implying concave indifference curves, such as ARB curve in Figure 1. Secondly, if they have a choice, would prefer either of them but not a combination of them. That is, Point A or B being on a lower Iso-probability curve touching at point $\mathrm{T}$ (not shown to avoid cluttering), would be preferred to point $\mathrm{R}$, which is on a higher indifference curve. However, from a policy perspective, a combination of both oversight and regulation would be more effective in preventing another financial crisis. Why? Since policies, if restricted only to the regulatory approach, would have serious limitations. First, rules and regulations are usually reactive dealing with to fix past problems and not proactive to prevent future ones. Secondly, note that an ant will succeed in finding a crack even in a magnificent building ${ }^{7}$ In due course, construction of a larger Matrix may be desirable.

Matrix 2. Inter-sectoral Linkages.

\begin{tabular}{|c|c|c|c|c|}
\hline & $\begin{array}{l}\text { Financials (banks, } \\
\text { brokerage firms, } \\
\text { hedge funds, etc.) }\end{array}$ & $\begin{array}{l}\text { Public } \\
\text { Sector }\end{array}$ & $\begin{array}{l}\text { Corporate Sector } \\
\text { (other than } \\
\text { financials) }\end{array}$ & $\begin{array}{l}\text { Household } \\
\text { Sector }\end{array}$ \\
\hline $\begin{array}{l}\text { Financials (banks, hedge } \\
\text { funds, brokerage firms etc.) }\end{array}$ & $\mathrm{A}_{11}$ & $\mathrm{~A}_{12}$ & $\mathrm{~A}_{13}$ & $\mathrm{~A}_{14}$ \\
\hline Public Sector & $\mathrm{A}_{21}$ & $\mathrm{~A}_{22}$ & $\mathrm{~A}_{23}$ & $\mathrm{~A}_{24}$ \\
\hline $\begin{array}{l}\text { Corporate Sector (other than } \\
\text { financials) }\end{array}$ & $A_{31}$ & $\mathrm{~A}_{32}$ & $\mathrm{~A}_{33}$ & $\mathrm{~A}_{34}$ \\
\hline Household Sector & $\mathrm{A}_{41}$ & $\mathrm{~A}_{42}$ & $\mathrm{~A}_{43}$ & $\mathrm{~A}_{44}$ \\
\hline
\end{tabular}




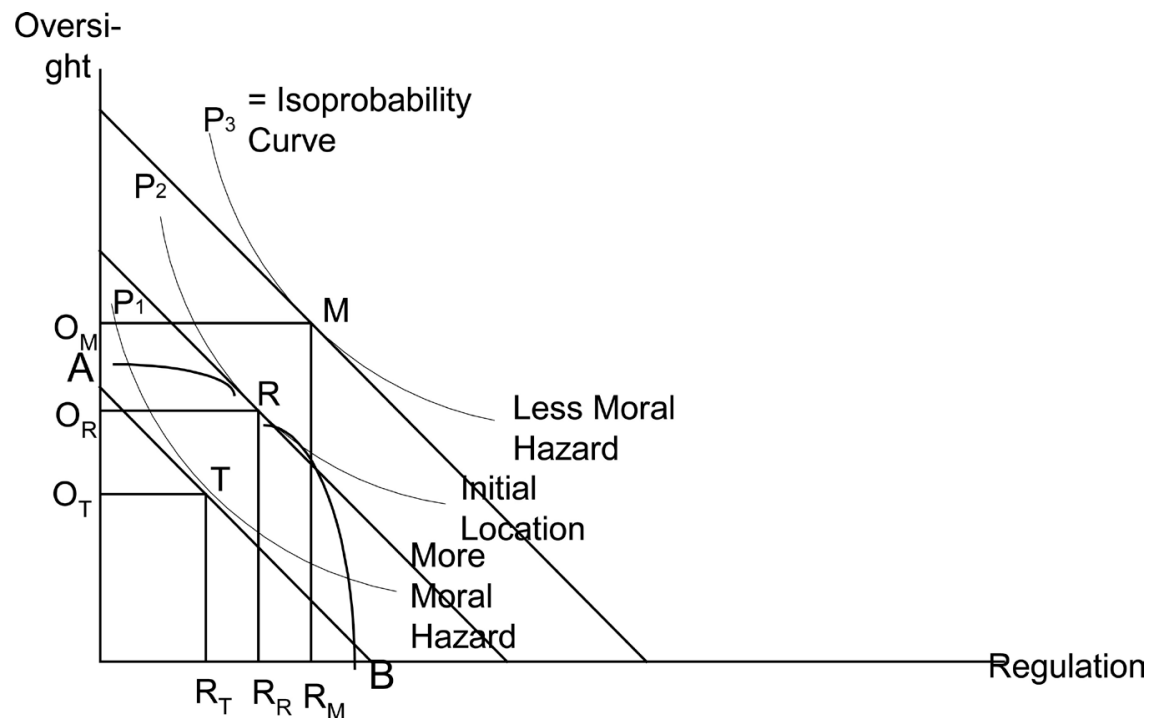

Figure 1. $\mathrm{P}_{1}, \mathrm{P}_{2}$, and $\mathrm{P}_{3}$ are the Iso-probability curves. Each Iso-probability curve indicates the various combinations of oversight and regulations required for achieving a certain level of probability for preventing a financial crisis.

like Taj Mahal. If you fill one it will find another. Similarly, some individuals within a short period of time would succeed in discovering loopholes in the laws and start exploiting them (known as regulatory arbitrage). However, DoddFrank legislation has established FSOC to "identify" and "respond" to emerging threats to the stability of the US financial system. That removes the deficiencies of the regulatory approach.

As an illustration, suppose the probability of preventing a financial crisis with regulations only $\mathrm{P}_{1}=0.85$. If both regulation and supervision were introduced, probability would increase to $P_{2}=0.95$. That means any repeal or weakening of Dodd-Frank legislation would raise the probability of a financial crisis. This is the risk we face now with its possible reversal by the new US administration. The following figure may be used to explain the roles of regulation, oversight and ethical grounding.

Kautilya was quite concerned about the possibility of moral decay and its potentially devastating impact on social-fabric, economic growth and stability. According to him, only self-discipline acquired through ethical grounding, could eliminate the problem of moral hazard, reduce white collar crimes and rent seeking activities and prevent another financial crisis. That is, without self-discipline, FSOC's twin objectives, prevention of financial crisis and promotion of market discipline, most probably would not be achieved. Moreover, ethical mooring is the most effective and least expensive way to preventing another financial crisis and improving corporate governance.

Regulations and supervision should be perceived as complements to ethical grounding and not as substitutes (see [10] Sihag (2014, Chapters. 5 and 6)). No amount of rules, regulations or supervision or their combination could effectively tackle the moral hazard problem, which has been the primary source of financial crises. Businesses find ways to circumvent regulations and supervision 
provisions and policy-makers also help the process by weakening the provisions. This is indicated by a shift of the initial Iso-probability curve $P_{2}$ to $P_{1}$. That is, probability of preventing crisis would decline over time. That is, given the predominantly amoral environment, reliance on oversight or regulations or their combination, most probably would not prevent another financial crisis. On the other hand, ethical grounding is the most effective and reliable tool that could motivate individuals not to waste energy in discovering and exploiting loopholes. Kautilya (p. 142) wrote, "Government by Rule of Law, which alone can guarantee security of life and welfare of the people, is, in turn, dependent on the self-discipline of the king (1.5)." With ethical grounding, over time the Iso-probability curve would shift upwards to $\mathrm{P}_{3}$, that is, the probability of preventing a financial crisis would increase. That is, if ethical conduct also were added to regulation and supervision, probability of prevention, most likely would be $\mathrm{P}_{3}=0.999$, that is, financial crisis would be almost non-existent.

\section{Kautilya on Definition and Building of Good Character}

Kautilya, like his predecessors, had a very comprehensive understanding of the concept of good character. According to him, good character meant practicing the dharmic (ethical) duties (mentioned above), such as non-violence, compassion, tolerance, truthfulness and freedom from malice and having self-discipline, which meant conquering six enemies "lust, anger, greed, conceit, arrogance and foolhardiness". The objective was to promote positive externalities and reduce negative ones. He believed good character would lead to good behavior. Table 1 presents his views on this relationship.

On the other hand, [11] Adam Smith (TMS, IV.2.8, p 189) wrote, "Self-command, in the same manner, by which we restrain our present appetites, in order to gratify them more fully upon another occasion, is approved of, as much under the aspect of propriety, as under that of utility....The spectator does not feel the solicitations of our present appetites. To him the pleasure which we are to enjoy a week hence, or a year hence, is just as interesting as that which we are to enjoy this moment."

The Impartial Spectator would not discount the future utility, implying absence of time preference. One may call this choice between present-self and the future-self as prudent but in no way ethical. More importantly, the concept of self-command is useless since it does not address the moral hazard problem and greed, which have negatively impacted the society. A person may have selfcommand and still commit white caller crimes. Moreover, this is an overuse of the impartial spectator since he should not be involved essentially in a saving decision. Interestingly, Eugene Soltes (2016) points out that this definition of selfcommand is still in use. He (p. 56) remarks, "In a well-known set of experiments from the early 1970s children were given the choice of receiving one marshmallow immediately or two if they waited until the researcher returned to the room." Whereas, self-discipline means giving up destructive emotions including greed, implying aversion to white collar crimes. 
Table 1. Kautilya on the link between character and behavior.

Ethical (Ruler, President, CEO)

Kautilya (p 145): "A rajarishi [a king, wise like a sage] is one who: has self-control, having conquered the [inimical temptations] of the senses, cultivates the intellect by association with elders, is ever active in promoting the security and welfare of the people, endears himself to his people by enriching them and doing good to them and avoids daydreaming, capriciousness, falsehood and extravagance (1.7)."

$\mathrm{He}$ ( $\mathrm{p}$ 149) wrote, "In the happiness of his subjects lies his happiness; in their welfare his welfare. He shall not consider as good only that which pleases him but treat as beneficial to him whatever pleases his subjects (1.19)." A king should take care of his subjects like a father takes care of his children. He (p. 128) wrote, "Whenever danger threatens, the king shall protect all those afflicted like a father [protects his children] (4.3)." He ( $\mathrm{p} \mathrm{180)}$ ) added, "He shall, however, treat leniently, like a father [would treat his son], those whose exemptions have ceased to be effective (2.1)." Kautilya ( $\mathrm{p}$ 128) believed, "It is the duty of the king to protect the people from all calamities (4.3)."

Kautilya (p 182) suggested, "King shall maintain, at state expense, children, the old, the destitute, those suffering from adversity, childless women and the children of the destitute women (2.1)."

$\mathrm{He}$ ( $\mathrm{p} 385$ ) stated, "The judges themselves shall take charge of the affairs of gods, Brahmins, ascetics, women, minors, old people, the sick and those that are helpless [e.g., orphans], [even] when they do not approach the court. No suit of theirs shall be dismissed for want of jurisdiction, passage of time or adverse possession (3.2)."
Unethical (Ruler, President, CEO)

Kautilya (p 133): “A decadent king, on the other hand, oppresses the people by demanding gifts, seizing what he wants and grabbing for himself and his favourites the produce of the country [i.e. the king and his coterie consume more than their due share thus considerably impoverishing the treasury and the people.] (8.4)." He (p $159)$ added that such a king: "Ignores the good [people] and favours the wicked, causes harm by new unrighteous practices; neglects the observation of the proper and righteous practices; suppresses dharma and propagates adharma; does what ought not to be done and fails to what ought to be done; fails to give what ought to be given and exacts what he cannot rightly take; "indulges in wasteful expenditure and destroys profitable undertakings"; does not punish those who ought to be punished but punishes those who do not deserve to be; arrests those who should not be arrested but fails to arrest who should be seized; "fails to protect the people from thieves and robs them himself"; "does not recompense service done to him"; "does not carry out his part of what had been agreed upon" "by his indolence and negligence destroys the welfare of his people" (7.5).

Eugene Soltes (2016, p. 63) continues, "If Judge Hellerstein is correct in suggesting that many of those sentenced for white-collar crimes are actually good people, we need to take a step back from focusing on the characteristics of the individuals involved and focus on the decisions being made by managers instead. Perhaps their failures arise not from "bad character" but, instead, from poor decisions made by otherwise typical individual." First, it is an untenable assertion to generalize based on a very small sample. Secondly, good people do not make deals with devils, like Rajaratnam ${ }^{8}$. Most importantly, a distinction needs to be made between "poor decisions" and illegal (unethical) decisions. These individuals made illegal (unethical) decisions not poor decisions and went to jail for doing that.

Samuel Buell (2016) considers context and situation more relevant than character in determining behavior. He (p. 20) remarks, "Anyone who has taken a course in psychology is familiar with one of the important discoveries of twentieth-century social science: people are wired to understand and explain each other's behavior with reference to character and disposition (she ran from the police, so she must not be law-abiding) rather than context and situation (if she ran from the police, may be the police have a pattern of wrongful arrests in the area) This is a common mistake. Situation generally has far more influence over people's behavior than do their prior tendencies."

${ }^{8}$ Confucius: "To see and listen to the wicked is already the beginning of wickedness."

https://www.brainyquote.com/quotes/authors/c/confucius_2.html 
A few comments are in order. First, self-protection is a basic instinct and it is hard wired. Secondly, it is an inappropriate way to bring out the importance of character since it is a case of using prior information (related to the past behavior of the cop) and not her prior disposition. More importantly, actually this illustration proves the point that character is important: it suggests that cops of bad-character would arrest and harass innocent people, that is, were more likely to do bad things.

Ethical Education: According to Kautilya, a concerted effort was required for ethical grounding, that is, it was not automatic or easy ${ }^{9}$. He (p. 137) believed, "Vices are due to ignorance and indiscipline; an unlearned man does not perceive the injurious consequences of his vices (8.3)." He (p. 144) stated, "The sole aim of all branches of knowledge is to inculcate restraint over the senses (1.6.3)." He (pp. 155-156) suggested, “'There can be no greater crime or sin', says Kautilya, 'than making wicked impressions on an innocent mind. Just as a clean object is stained with whatever is smeared on it, so a prince, with a fresh mind, understands as the truth whatever is taught to him ${ }^{10}$. Therefore, a prince should be taught what is dharma and artha, not what is unrighteous and materially harmful (1.17).”

\section{Conclusions}

Kautilya's Arthashastra is a manual on engineering prosperity and preventing crisis. Under the current environment in which heavy emphasis is put on materialism, it is unrealistic to expect people not to exploit loopholes or not harm through their amoral and immoral behavior ${ }^{11}$. However, according to Kautilya, ethical grounding of children was possible.

Stress test is used to diagnose heart failure, a physical condition, not moral failure, which is a primary source of systemic risk. That is, the stress test is not a reliable guide to predicting financial crisis. This paper's major limitation is that it focused only on US since the recent financial crisis originated from its financial institutions and still poses threats to world financial stability. However, incorporation of European experiences and policies could significantly enrich the

${ }^{9}$ Development of Self-Command: According to Smith (TMS III.22, p. 145), "When it is old enough to go to school, or to mix with its equals, it soon finds that they have no such indulgent partiality. It naturally wishes to gain their favour, and to avoid their hatred or contempt. Regard even to its own safety teaches it to do so; and it soon finds that it can do so in no other way than by moderating, not only its anger, but all its other passions, to the degree which its play-fellows and companions are likely to be pleased with. It thus enters into the great school of self-command, it studies to be more and more master of itself, and begins to exercise over its own feelings a discipline which the practice of the longest life is very seldom sufficient to bring to complete perfection."

First, if it was that automatic and easy to develop self-command, there would be no need to pass legislation to stop bullying in schools or to install metal detectors in many schools. Secondly, socially meaningful role of self-command is to conquer greed but that is left out, implying it serves no purpose.

${ }^{10}$ On the hand, Eugene Soltes (2016, p. 60) remarks, "WE'RE NOT BORN with a "blank slate," nor do inherited or genetic dispositions entirely determine our behavior."

${ }^{11}$ [16] Williamson (1985, p. 47) characterizes the potential behavior of the other firm as: "calculated efforts to mislead, disguise, obfuscate, or otherwise confuse" and "seeking self-interest, but they do so with guile". 
analysis.

Former Fed Chairman Ben Bernanke had repeatedly expressed his concerns about the potential impact of the recent Great recession as: "What was clear to me was that we were at tremendous risk for another Great Depression. If the financial system collapsed, it would bring down everything. It wouldn't just be folks on Wall Street who would be suffering, but it would be people in the heartland who would also be hit." That implies that systemic risk could end up as systematic risk. Therefore, it is desirable to explore their relationship to each other and not study them separately as currently done by [12] Barro and Ursua (2012) and Zigrand (2014) ${ }^{12}$.

\section{References}

[1] Sanchis, M. (2014) The Economics of the Monetary Union and the Eurozone Crisis. Springer Brief in Economics, Springer, Heidelberg, 81-82.

[2] Ortega y Gasset, J. (2010) El hombre y su circunstancia. Madrid, Fundación José Ortega y Gasset-Taurus, Complete Works, Vol. 8, 499-511.

[3] Samuel, B.W. (2016) Capital Offenses. Norton \& Company, New York.

[4] Eugene, S. (2016) Why They Do It. Publicaffairs, New York.

[5] Vishnugupta, K. 1992) The Arthashastra. Translated and Introduced by Rangarajan, L.N., Penguin Books, New Delhi.

[6] Jean-Pierre, Z. (2014) Systems and Systemic Risk in Finance and Economics. Systemic Risk Centre, London School of Economics, London.

www.systemicrisk.ac.uk

[7] Sanchis, M. (2014) El fracaso de las élites. Cómo reparar los daños de Gran Recesión. Pasado \& Presente, Barcelona, 153.

Colander, D., Föllmer, H., Haas, A., Goldberg, M., Juselius, K., Kirman, A., Lux, T. and y Sloth, B. (2009) The Financial Crisis and the Systemic Failure of Academic Economics. Kiel Working Papers, No. 1489, Kiel Institute for the World Economy, Kiel, 17 p.

[8] Zachary, F., Rudloffb, B. and Weber, S. (2016) Measures of Systemic Risk. https://arxiv.org/pdf/1502.07961.pdf

[9] Samhita, A.-V. (2004) Article Title. Edited and Revised by Joshi, K.L., Parimal Publications, New Delhi.

[10] Sihag, B.S. (2014) Kautilya: The True Founder of Economics. Vitasta Publishing, New Delhi.

[11] Adam, S. (1790/1982) The Theory of Moral Sentiments. Edited by Raphael, D.D. and Macfie, A.L., Liberty Fund, Indianapolis.

[12] Barro, R.J. and Ursua, J.F. (2012) Rare Macroeconomic Disasters. Annual Review of Economics, 4, 83-109. https://doi.org/10.1146/annurev-economics-080511-110932

[13] Mark, E., Hortacsu, A. and Matvos, G. (2017) Deposit Competition and Financial Fragility: Evidence from the US Banking Sector. American Economic Review, 107, 169-216. https://doi.org/10.1257/aer.20150342

\footnotetext{
${ }^{12}$ Jean-Pierre Zigrand, "Typical examples of systematic risk would be aggregate technology shocks, aggregate endowment, output, preference or monetary shocks etc. These systematic events may correspond to very large shocks, such as for instance the power-law shocks in Gabaix (2009) and Barro and Urs'ua (2012), but the system is expected to continue functioning normally and properly. This distinction has also been emphasised by Hansen (20 12)."
} 
[14] Christoffer, K., Richardson, G. and Van Horn, P. (2016) Bank Leverage and Regulatory Regimes: Evidence from the Great Depression and Great Recession. American Economic Review, 106, 538-542. https://doi.org/10.1257/aer.p20161045

[15] Brunnermeier, M.K. and Oehmke, M. (2012) Bubbles, Financial Crises, and Systemic Risk. Working Paper 18398, National Bureau of Economic Research. http://www.nber.org/papers/w18398

[16] Williamson, O.E. (1985) The Economic Institutions of Capitalism: Firms, Markets, Rational Contracting. Collier Macmillan, London.

Submit or recommend next manuscript to SCIRP and we will provide best service for you:

Accepting pre-submission inquiries through Email, Facebook, LinkedIn, Twitter, etc. A wide selection of journals (inclusive of 9 subjects, more than 200 journals)

Providing 24-hour high-quality service

User-friendly online submission system

Fair and swift peer-review system

Efficient typesetting and proofreading procedure

Display of the result of downloads and visits, as well as the number of cited articles Maximum dissemination of your research work

Submit your manuscript at: http://papersubmission.scirp.org/

Or contact tel@scirp.org 